\title{
Conformational transmission in the glyceryl backbone of phospholipid model compounds, induced by a P(4- coordinated) into trigonal bipyramidal $P(5$-coord) transition
}

Citation for published version (APA):

Meulendijks, G. H. W. M., Es, van, W., Haan, de, J. W., \& Buck, H. M. (1986). Conformational transmission in the glyceryl backbone of phospholipid model compounds, induced by a $\mathrm{P}$ (4-coordinated) into trigonal bipyramidal P(5-coord) transition. European Journal of Biochemistry, 157(2), 421-426.

https://doi.org/10.1111/j.1432-1033.1986.tb09684.x

DOI:

10.1111/j.1432-1033.1986.tb09684.x

Document status and date:

Published: 01/01/1986

Document Version:

Publisher's PDF, also known as Version of Record (includes final page, issue and volume numbers)

Please check the document version of this publication:

- A submitted manuscript is the version of the article upon submission and before peer-review. There can be important differences between the submitted version and the official published version of record. People interested in the research are advised to contact the author for the final version of the publication, or visit the DOI to the publisher's website.

- The final author version and the galley proof are versions of the publication after peer review.

- The final published version features the final layout of the paper including the volume, issue and page numbers.

Link to publication

\footnotetext{
General rights

- You may freely distribute the URL identifying the publication in the public portal. follow below link for the End User Agreement:

www.tue.nl/taverne

\section{Take down policy}

If you believe that this document breaches copyright please contact us at:

openaccess@tue.nl

providing details and we will investigate your claim.
}

Copyright and moral rights for the publications made accessible in the public portal are retained by the authors and/or other copyright owners and it is a condition of accessing publications that users recognise and abide by the legal requirements associated with these rights.

- Users may download and print one copy of any publication from the public portal for the purpose of private study or research.

- You may not further distribute the material or use it for any profit-making activity or commercial gain

If the publication is distributed under the terms of Article 25fa of the Dutch Copyright Act, indicated by the "Taverne" license above, please 


\title{
Conformational transmission in the glyceryl backbone of phospholipid model compounds, induced by a P(4-coordinated) into trigonal bipyramidal $\mathbf{P}(5$-coord) transition
}

\author{
Gijsbert H. W. M. MEULENDIJKS, Wilma VAN ES, Jan W. DE HAAN and Henk M. BUCK \\ Department of Organic Chemistry, Eindhoven University of Technology
}

(Received November 13, 1985/February 27, 1986) - EJB 851239

\begin{abstract}
Triesterified phospholipid model compounds have been synthesized and extensively studied with $300-\mathrm{MHz}$ ${ }^{1} \mathrm{H}$ NMR in the monomer phase in order to get additional support for the effect of conformational transmission induced by a $\mathrm{P}(4-$ coord $)$ into a trigonal bipyramidal $\mathrm{P}$ (5-coord) transition, as was suggested by Merkelbach and Buck. To elucidate any conformational preferences around the $\mathrm{C}^{2}-\mathrm{C}^{3}$ bond, the stereospecifically deuterated precursor 1,2-dihexanoyl- $(3 R)-s n-\left[3-{ }^{2} \mathrm{H}\right] \mathrm{glycerol}$ was synthesized. The results reveal that a coordinational change of phosphorus from four to five is transmitted in a significant increase in population of the conformer, in which the vicinally substituted oxygens $\mathrm{O}-2$ and $\mathrm{O}-3$ are trans located. The impact of this transmission seems not to be restricted to conformational changes in the adjacent $\mathrm{C}^{2}-\mathrm{C}^{3}$ bond, but is also present in specific rotations around the $\mathrm{C}^{1}-\mathrm{C}^{2}$ bond, thereby shifting the $\mathrm{C}^{1}-\mathrm{C}^{2}$ conformational equilibrium towards a decreased contribution of the trans arrangement of the acyl chains. As a consequence the interchain distance will be reduced and thus van der Waals interactions will be maximized. The results are interpreted in terms of increased electron density on $\mathrm{O}-3$ when axially located in a $\mathrm{P}$ (5-coord) trigonal bipyramidal compound, thereby introducing enhanced electrostatic repulsions within the oxygen pairs $\mathrm{O}-3, \mathrm{O}-2$ and $\mathrm{O}-3, \mathrm{O}-1$. Relaxation of this energetically unfavourable geometry leads to the observed conformational shifts. Absence of conformational transmission, as found in $\mathrm{P}(5$-coord) trigonal bipyramidal compounds with the 2-ester group substituted for an alkyl moiety, can be considered as additional support for the introduced concept. In the alkyl part of the model phospholipids, however, no conformational changes were observed by means of ${ }^{13} \mathrm{C}$ NMR. Extrapolating this outcome to more condensed phases, a proposition could be made about the mechanism by which conformational changes in the head-group and/or glyceryl backbone will be compensated.
\end{abstract}

Phospholipids have been the subject of numerous conformational studies in order to get some insight in their behaviour in biomembranes [1,2]. In this paper we wish to present some experimental results on the conformational transmission from the phospholipid head-group towards the hydrocarbon chains upon a coordinational change of phosphorus from four to five. The role of $\mathrm{P}(5$-coord $)$ trigonal bipyramidal (TBP) intermediates in phospholipid membranes as a trigger for ion transport has been discussed by Merkelbach and Buck [3, 4]. These intermediates, visualized as the result of an attack of, for instance, water on a P(4coord) geometry, are stabilized by a pseudo-six-membered ring in an equatorial arrangement, originating from the choline moiety by charge attraction.

Earlier theoretical and experimental investigations conducted in this laboratory on 5-phosphorylated tetrahydrofurfuryls $[5,6]$, which possess essentially the same P-O-C-C-O

Correspondence to G. H. W. M. Meulendijks, Laboratorium voor Organische Chemie, Technische Hogeschool Eindhoven, Postbus 513, NL-5600 MB Eindhoven, The Netherlands

Abbreviations. TBP, trigonal bipyramidal; $\mathrm{P}$ (5-coord), 5-coordinated phosphorus.

Enzymes. Diaphorase from pig heart (EC 1.6.4.3); horse liver alcohol dehydrogenase (EC 1.1.1.1). sequence as encountered in phospholipids, have already shown that $\mathrm{P}(5$-coord) TBP geometries bring about specific rotations in the adjacent $\mathrm{C}-\mathrm{C}$ bond if the tetrahydrofurfuryl group occupies an axial position in the TBP. Virtually no conformational transmission effects were found for an equatorial location. Despite the process of phosphorus pseudorotation, which involves a fast intramolecular ligand exchange between the axial and equatorial sites, a significantly greater population in comparison with the $\mathrm{P}(4$-coord) counterpart was found for the conformer in which the vicinally substituted O-1 and O-5 are trans located. The specific rotations are attributed to the enhanced repulsion between $\mathrm{O}-1$ and $\mathrm{O}-5$ as a consequence of the extra electron density on $\mathrm{O}-5$ when axially located in the TBP.

In order to gather experimental evidence for the conformational transmission in phospholipids, a set of triesterified P(4-coord) and P(5-coord) TBP phospholipid model compounds was synthesized and the rotameric distributions in the glyceryl backbone were studied with $300-\mathrm{MHz}^{1} \mathrm{H}$ NMR.

For the conformational analysis a correct assignment of the $\mathrm{H}-1 R, \mathrm{H}-1 S, \mathrm{H}-3 R$ and $\mathrm{H}-3 S$ protons is a prerequisite. For that purpose the stereospecifically deuterated 1,2-dihexanoyl$(3 R)-s n-\left[3-{ }^{2} \mathrm{H}\right]$ glycerol was synthesized from which the $\mathrm{P}(4-$ coord) and P(5-coord) TBP compounds were derived. The results of the conformational analysis around $\mathrm{C}^{2}-\mathrm{C}^{3}$ and $\mathrm{C}^{1}$ - 
$\mathrm{C}^{2}$ show that a transition form $\mathrm{P}$ (4-coord) into $\mathrm{P}(5$-coord) TBP is indeed transmitted into specific rotations in the glyceryl backbone. Furthermore we examined whether these conformational changes were carried over in specific shifts in the conformational equilibria of the hydrocarbon chains. Such changes can easily be probed with ${ }^{13} \mathrm{C}$ chemical shifts, as was demonstrated in this laboratory [7]. Contrary to expectation the results indicate that no detectable changes occur in the acyl conformational equilibria upon an increase in coordination round phosphorus from four to five. Although the results from the conformational analysis are only valid for the monomeric phase, a prediction could be made about the mechanism by which conformational changes in the headgroup and/or glyceryl backbone will be compensated.

\section{MATERIALS AND METHODS}

\section{Spectroscopy}

${ }^{1} \mathrm{H}$ NMR spectra were recorded at $300.13 \mathrm{MHz}$ on a Bruker CXP 300 spectrometer at room temperature. Coupling constants were derived by iterative fitting of expansions of the $\mathrm{H}-1 S / \mathrm{H}-1 R$ and $\mathrm{H}-3 S / \mathrm{H}-3 R$ patterns, using the program PANIC-82 (Bruker Spectrospin). ${ }^{31} \mathrm{P}$ spectra were run on a Bruker HX-90R spectrometer with a Digilab FT-NMR-3 pulsing accessory. ${ }^{13} \mathrm{C}$ spectra were run at $75.47 \mathrm{MHz}$ on a Bruker CXP 300 spectrometer under proton noise decoupling at $37^{\circ} \mathrm{C} .656$ Transients were accumulated of spectral width $1.5 \mathrm{kHz}$ in $32 \mathrm{k}$ data points. All NMR samples were routinely dissolved in $\mathrm{CDCl}_{3}$, unless otherwise stated.

\section{Materials}

All solvents were reagent grade and were used as received or purified as required. All reactions involving $\mathrm{P}$ (3-coord) or $\mathrm{P}(5$-coord) compounds were run under a dry and inert atmosphere. Horse liver alcohol dehydrogenase and diaphorase with the coenzyme FAD from pig heart were purchased from Boehringer Mannheim. NAD ${ }^{+}, \mathrm{NADH}$ and albumin were products of Sigma.

\section{Synthesis}

The $\mathrm{P}$ (4-coord) and $\mathrm{P}$ (5-coord) TBP derivatives were synthesized according to known procedures [5, 8-15]. All of the isolated intermediates were characterized by ${ }^{1} \mathrm{H} \mathrm{NMR}$, boiling point and by comparing these properties with literature data. Experimental data on the P(4-coord) and $\mathrm{P}(5-$ coord) TBP compounds, which were not characterized before, are compiled in Table 4. A typical procedure will be given for the synthesis of (1,2-dihexanoyl- $(3 R)$-sn-[3- $\left.{ }^{2} \mathrm{H}\right]$ glycero $) \mathrm{di}-$ methoxyphosphine oxide $\left(1 \mathrm{a}-\mathrm{d}_{1}\right)$ and $2,2-$ dimethoxy-2-(1,2dihexanoyl-(3R)-sn-[3-2 H]glycero)-2,2-dihydro-4,5-dimethyl1,3,2-dioxaphosphol-4-ene $\left(1 \mathrm{~b}-\mathrm{d}_{1}\right)$.

The precursor 1,2-isopropylidene- $(3 R)-s n-\left[3-{ }^{2} \mathrm{H}\right]$ glycerol was prepared from 1,2-isopropylidene-sn-glycerol $[9,10]$, as described by Wohlgemuth et al. [16]. Immediately before use the enzyme suspensions were centrifuged $(3000 \mathrm{rpm}, 4 \mathrm{~min}$ at $20^{\circ} \mathrm{C}$ ) and the clear supernatant removed. The extent of deuteration amounted to $65 \%$ as judged by the ${ }^{1} \mathrm{H}$ NMR integral. The alcohol was protected by treatment with sodium, followed by benzyl chloride. The isopropylidene group was hydrolyzed in $10 \%$ acetic acid/water at $100^{\circ} \mathrm{C}$ and the resulting clear solution concentrated [11, 12]. Toluene was added and the solvent was evaporated. The product was dried in vacuo at $40^{\circ} \mathrm{C}$. The obtained 3 -benzyl- $(3 R)-s n-\left[3-{ }^{2} \mathrm{H}\right]$ glycerol was acylated by adding hexanoyl chloride to a solution of the benzylglycerol in dry toluene at $0^{\circ} \mathrm{C}$. The solution was allowed to stand overnight at room temperature and the product was worked up following usual procedures. Purification of the residue by column chromatography on silica and using chloroform/acetone (96/4) as eluent, yielded pure 1,2-dihexanoyl-3-O-benzyl- $(3 R)-s n-\left[3-{ }^{2} \mathrm{H}\right]$ glycerol, which was converted into the 1,2-dihexanoyl- $(3 R)-s n-\left[3-{ }^{2} \mathrm{H}\right]$ glycerol by hydrogenolysis in ethyl acetate catalyzed by $10 \% \mathrm{Pd} / \mathrm{C}$, just before the next reaction [12]. The alcohol was phosphorylated with chlorodimethoxyphosphine [13] and converted into the $\mathrm{P}(4-$ coord) and P(5-coord) TBP derivatives with ozone and butanedione respectively, following similar procedures as outlined by Koole et al. [5].

\section{RESULTS AND DISCUSSION}

\section{Assignment of the proton resonances}

The proton resonances of $\mathrm{H}-3 R$ and $\mathrm{H}-3 S$ can be assigned unequivocally when a hydrogen is replaced stereospecifically by deuterium. This exchange was enzymatically achieved, making use of the known stereochemistry introduced by alcohol dehydrogenase, which catalyzes the oxidation of primary alcohols by abstracting the pro- $R$ hydrogen. A diaphorase enzyme (with the coenzyme FAD) accomplishes the exchange between the hydrogen of coenzyme NADH and the deuterium of the solvent $\mathrm{D}_{2} \mathrm{O}[16,17]$. Using this approach, 1,2isopropylidene-sn-glycerol, obtained form D-mannitol, was converted into the $3 R$ deuterated analogue and via known procedures the (deuterated) structures $1 \mathrm{a}$ and $1 \mathrm{~b}$ shown in Fig. 1 were synthesized. An expansion of the H-3 NMR pattern of the deuterated $\mathrm{P}$ (4-coord) compound $1 \mathrm{a}$ reveals that the downfield proton is exchanged by deuterium (Fig. 2), thus this hydrogen can be assigned as pro- $R$. (The enantiomerically pure alcohol must be used, otherwise a diastereomeric mixture is obtained after the stereospecific $H / D$ exchange, in which the $H-3 S$ protons are magnetically inequivalent. $)$ In the $P(5$ coord) TBP compound $1 \mathrm{~b}$ the chemical shift difference between $\mathrm{H}-3 R$ and $\mathrm{H}-3 \mathrm{~S}$ is almost identical with the isotope effect $(0.02 \mathrm{ppm})$, which causes an upfield shift of the remaining hydrogen [18]. For deuterated $1 \mathrm{~b}$ a signal was observed $0.02 \mathrm{ppm}$ upfield with respect to the upfield proton in the non-deuterated analogue, thus this resonance comes from the pro- $S$ proton. For $1 \mathrm{a}$ and $1 \mathrm{~b}$ it is now firmly established that $\delta(\mathrm{H}-3 R)>\delta(\mathrm{H}-3 S)$ and we will use this assignment for the compounds $1-5$. For the $\mathrm{H}-1 R$ and $\mathrm{H}-1 S$ protons the same assignment was applied as was determined for dihexanoylglycerophosphocholine $[\delta(\mathrm{H}-1 R)<\delta(\mathrm{H}-1 S)]$ and which accounts for the well-known parallel orientation of the hydrocarbon chains [2].

\section{Conformational analysis}

In solution rapid interconversion between the staggered conformers $g^{+}, g^{t}$ and $g^{-}$(Fig. 3) yields weighted timeaveraged vicinal coupling constants $J_{\mathrm{H}-2 \mathrm{H}-1 \mathrm{~s}}, J_{\mathrm{H}-2 \mathrm{H}-1 R}, J_{\mathrm{H}-2}$ $\mathrm{H}-3 \mathrm{~s}$ and $J_{\mathrm{H}-2 \mathrm{H}-3 \mathrm{R}}$, which are related to the coupling constants in the individual rotamers and their mole fractions $x\left(g^{+}\right)$, $x\left(g^{t}\right)$ and $x\left(g^{-}\right): J_{\mathrm{H}-2 \mathrm{H}-i S(\mathrm{H}-i R)}=x\left(g^{+}\right) J_{\mathrm{H}-2 \mathrm{H}-i S(\mathrm{H}-i R)}^{g^{2}}+x\left(g^{t}\right)$

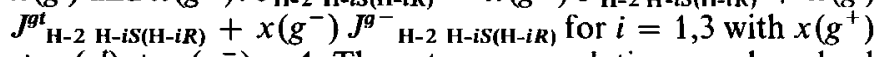
$+x\left(g^{t}\right)+x\left(g^{-}\right)=1$. The rotamer populations can be solved with the coupling constants of the $g^{+}, g^{t}$ and $g^{-}$rotamers 


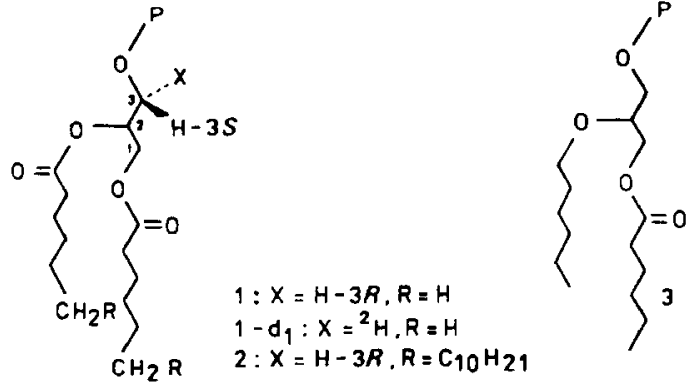

a $P(4-\operatorname{coord})=\mathrm{MeO}_{\mathrm{P}}=0$

Fig.1. Structures of the phospholipid model compounds studied by NMR
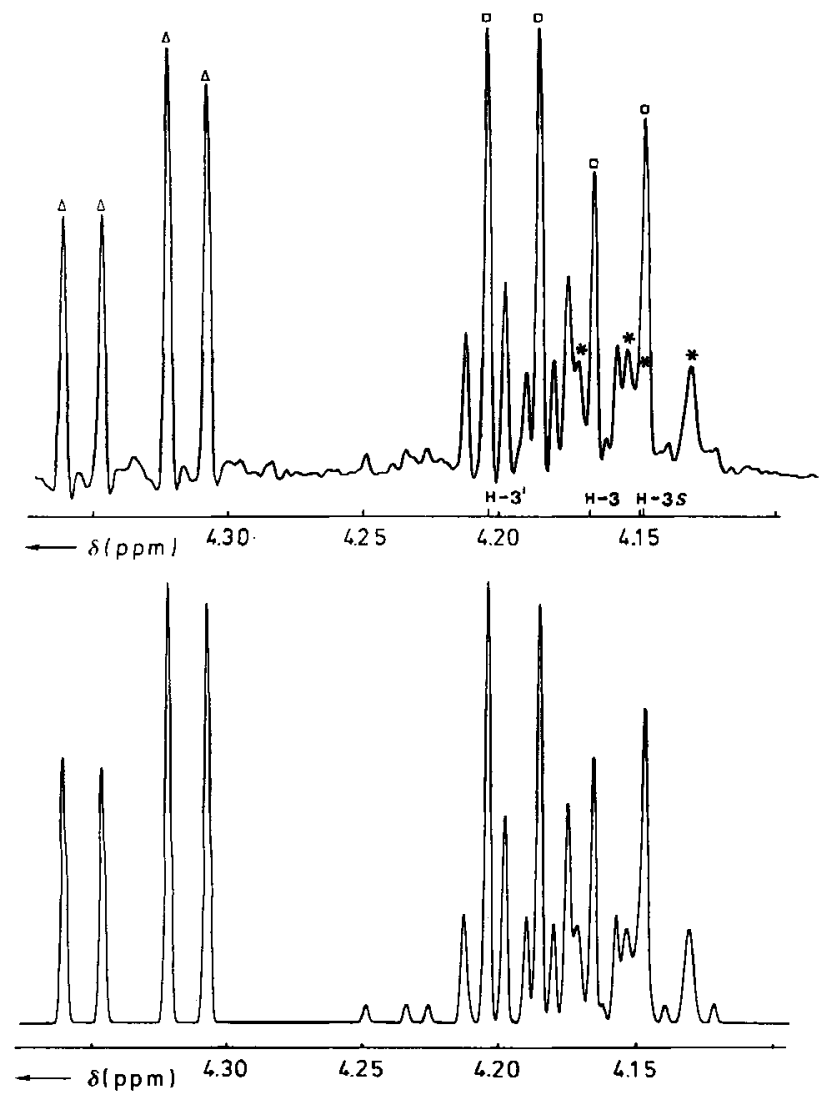

Fig.2. Experimental (upper trace) and computer-simulated (lower trace) $300-M H z{ }^{1} H$-NMR spectrum of $1 a-d_{1}$ in $\left({ }^{2} H_{1}\right)$ chloroform. The asterisks point out the $\mathrm{H}-3 S$ pattern. The other signals belong to $\mathrm{H}-1 R(\square), \mathrm{H}-1 S(\triangle)$ and $\mathrm{H}-3 / \mathrm{H}-3^{\prime}$, of the non-deuterated fraction

obtained from an empirical generalized Karplus equation developed by Altona et al. [19] ${ }^{1}$.

As can be seen from the data in Table 1, the rotameric distribution around the $\mathrm{C}^{2}-\mathrm{C}^{3}$ bond of the $\mathrm{P}(4-$ coord $)$

${ }^{1}$ In this generalized equation the standard Karplus relation is extended with a correction term which accounts for the influence of electronegative substituents on ${ }^{3} J_{\mathrm{HH}}:{ }^{3} J_{\mathrm{HH}}=13.22 \cos ^{2} \varphi-0.99 \cos$ $\varphi+\Sigma\left[0.87-2.46 \cos ^{2}\left(\xi_{i} \varphi+19.9\left|\Delta \chi_{\mathrm{i}}\right|\right)\right] \Delta \chi_{\mathrm{i}} ; \varphi$ is the dihedral angle between the protons, $\Delta \chi$ is the difference in electronegativity between the substituent and hydrogen according to the electronegativity scale of Huggins and $\xi$ is a substituent orientation parameter.
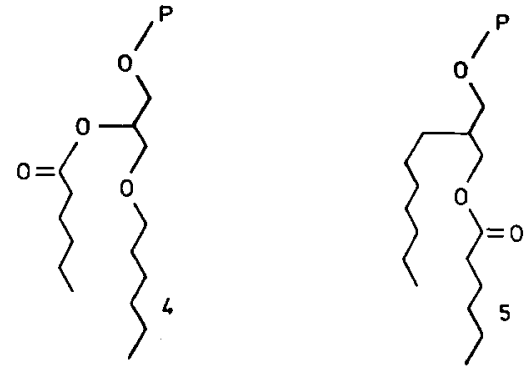

$b P(5-\operatorname{coor} d)-T B P=M_{M e O}=P_{0}^{M e}$

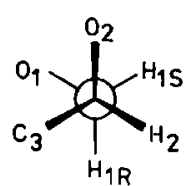

$g^{+}$

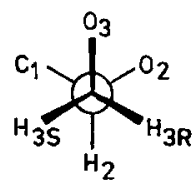

$g^{+}$<smiles>C[C@@H]1[C@H](P)[C@@H](O)[C@H](CS)[C@H]1O</smiles>

$g^{t}$

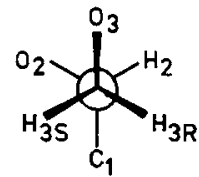

$g^{t}$

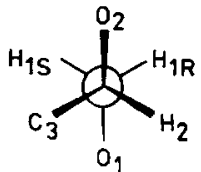

$g^{-}$

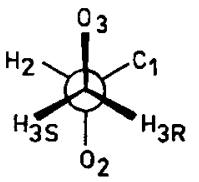

g- $^{-}$
Fig. 3. Newman projections of the rotamers around $C^{1}-C^{2}$ (upper trace) and $C^{2}-C^{3}$ (lower trace). For clearity, the $\mathrm{C}^{1}-\mathrm{C}^{2}$ rotamer in which the oxygens are trans located, is indicated as $g^{-}$, despite of the conventional rules

compounds $1 \mathrm{a}$ to $4 \mathrm{a}$ in various solvents is dominated by the gauche effect, i.e. the preference of vicinally orientated oxygens to adopt a gauche conformation $[20]\left(\mathrm{C}^{2}-\mathrm{C}^{3}: x\left(g^{+}\right)\right.$ $=0.40-0.47, x\left(g^{t}\right)=0.37-0.47$ and $\left.x\left(g^{-}\right)=0.10-0.23\right)$. Upon lowering the solvent polarity, the increase in the electrostatic charge repulsion between $\mathrm{O}-2$ and $\mathrm{O}-3$ leads to a conformational change for the $\mathrm{C}^{2}-\mathrm{C}^{3}$ bond in favour of the $\mathrm{g}^{-}$conformer. This outcome is in good agreement with the observation on model nucleotides [6]. The $\mathrm{C}^{1}-\mathrm{C}^{2}$ rotamer distribution, on the other hand, is governed by the tendency of the hydrocarbon chains to adopt a parallel orientation, which will be more pronounced in polar solvents, thereby excluding a large contribution of the $g^{-}$conformer.

For compound $3 \mathrm{a}$, in which the $s n-2$ chain is linked by an ether bond to the glyceryl backbone, a slightly increased $g$ population around $C^{2}-C^{3}$ and $C^{1}-C^{2}$ is observed compared to the 2-ester analogue $1 \mathrm{a}$ [for $\mathrm{CDCl}_{3}, \mathrm{C}^{2}-\mathrm{C}^{3}: x\left(g^{-}\right)=0.23$ cf. $0.20 ; \mathrm{C}^{1}-\mathrm{C}^{2}: x\left(g^{-}\right)=0.75 \mathrm{cf}$. 0.19]. This finding is obviously due to the enhanced electron density on $\mathrm{O}-2$ in 3 a with respect to $1 \mathrm{a}$. When the 2-ester group is substituted by an alkyl moiety, as in $5 \mathrm{a}$, virtually no shifts in conformer populations are detectable around the $\mathrm{C}^{2}-\mathrm{C}^{3}$ bond upon increasing solvent polarity. Identical distributions were also found for the $\mathrm{C}^{1}-\mathrm{C}^{2}$ bond in various solvents. Apparently the 2-ester moiety plays a crucial role in alterations in the $\mathrm{C}^{1}-\mathrm{C}^{2}$ conformational equilibrium. 
Table 1. $\mathrm{J}_{H-2}{ }_{H-1} \mathrm{~S}(H-1 \mathrm{R})$ and $\mathrm{J}_{H-2} H_{-3 \mathrm{~S}}(\mathrm{H}-3 \mathrm{R})$ values and the corresponding rotamer populations around $C^{1}-C^{3}$ and $C^{2} \cdot C^{3}$ for the $P(4-c o o r d)$ compounds in various solvents at room temperature

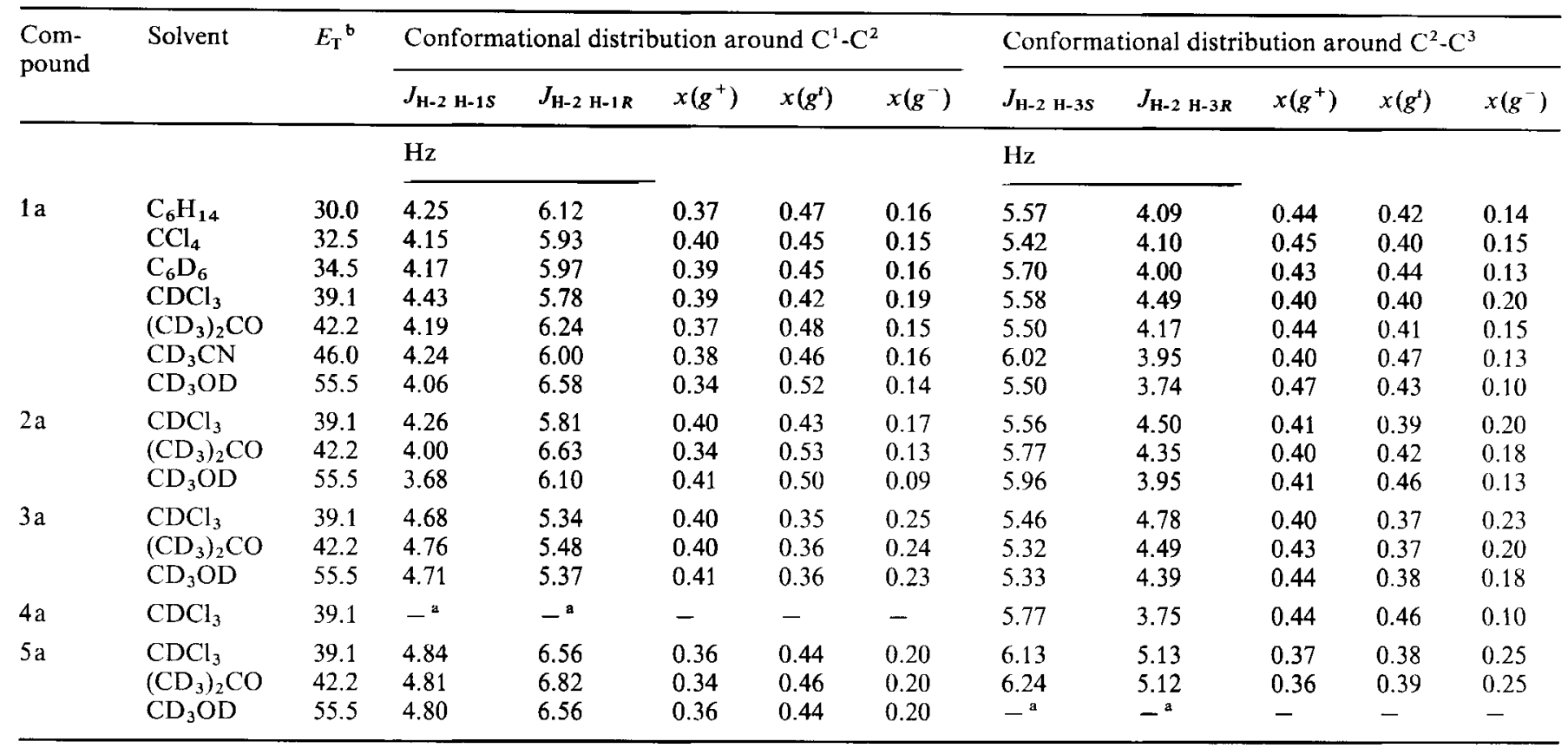

The coupling constants could not be determined accurately.

${ }^{b} E_{\mathrm{T}}$ is an empirical solvent polarity parameter.

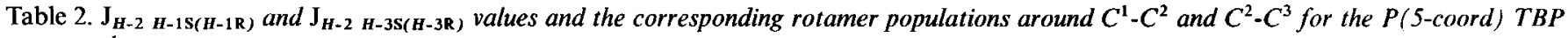
compounds at room temperature

\begin{tabular}{|c|c|c|c|c|c|c|c|c|c|c|c|c|}
\hline $\begin{array}{l}\text { Com- } \\
\text { pound }\end{array}$ & Solvent & $E_{\mathrm{T}}^{\mathrm{b}}$ & \multicolumn{5}{|c|}{ Conformational distribution around $\mathrm{C}^{1}-\mathrm{C}^{2}$} & \multicolumn{5}{|c|}{ Conformational distribution around $\mathrm{C}^{2}-\mathrm{C}^{3}$} \\
\hline $1 \mathrm{~b}$ & $\begin{array}{l}\mathrm{C}_{6} \mathrm{H}_{14} \\
\mathrm{C}_{6} \mathrm{D}_{6} \\
\mathrm{CDCl}_{3} \\
\left(\mathrm{CD}_{3}\right)_{2} \mathrm{CO} \\
\mathrm{CD}_{3} \mathrm{CN}\end{array}$ & $\begin{array}{l}30.0 \\
34.5 \\
39.1 \\
42.2 \\
46.0\end{array}$ & $\begin{array}{l}3.52 \\
3.60 \\
3.60 \\
3.62 \\
3.74\end{array}$ & $\begin{array}{l}6.53 \\
6.60 \\
6.63 \\
6.78 \\
6.59\end{array}$ & $\begin{array}{l}0.37 \\
0.37 \\
0.38 \\
0.35 \\
0.36\end{array}$ & $\begin{array}{l}0.55 \\
0.55 \\
0.50 \\
0.55 \\
0.54\end{array}$ & $\begin{array}{l}0.08 \\
0.08 \\
0.12 \\
0.10 \\
0.10\end{array}$ & $\begin{array}{l}5.21 \\
5.28 \\
5.38 \\
5.45 \\
5.70\end{array}$ & $\begin{array}{l}5.37 \\
5.36 \\
5.47 \\
5.06 \\
5.03\end{array}$ & $\begin{array}{l}0.37 \\
0.38 \\
0.36 \\
0.38 \\
0.36\end{array}$ & $\begin{array}{l}0.32 \\
0.31 \\
0.36 \\
0.35 \\
0.38\end{array}$ & $\begin{array}{l}0.31 \\
0.31 \\
0.28 \\
0.27 \\
0.26\end{array}$ \\
\hline $2 b$ & $\mathrm{CDCl}_{3}$ & 39.1 & 3.60 & 6.63 & 0.37 & 0.55 & 0.08 & 5.38 & 5.47 & 0.35 & 0.32 & 0.33 \\
\hline $3 b$ & $\mathrm{CDCl}_{3}$ & & 3.81 & 6.00 & 0.41 & 0.48 & 0.11 & 6.24 & 5.35 & 0.27 & 0.42 & 0.31 \\
\hline $4 b$ & $\mathrm{CDCl}_{3}$ & & $-{ }^{a}$ & $-{ }^{a}$ & - & - & - & 5.75 & 4.44 & 0.40 & 0.42 & 0.18 \\
\hline $5 b$ & $\mathrm{CDCl}_{3}$ & & 5.31 & 6.26 & 0.35 & 0.38 & 0.27 & 5.91 & 5.27 & 0.38 & 0.36 & 0.26 \\
\hline
\end{tabular}

a The coupling constants could not be determined accurately.

${ }^{b} E_{\mathrm{T}}$ is an empirical solvent polarity parameter.

Comparing the data of Table 1 and Table 2 it follows that a coordinational change from $\mathrm{P}(4$-coord) into $\mathrm{P}(5$-coord $)$ TBP brings about a significant increase in $g^{-}$population around $\mathrm{C}^{2}-\mathrm{C}^{3}$ [for $\mathrm{CDCl}_{3}, \mathrm{P}(4$-coord $): x\left(g^{-}\right)=0.10-0.23 ; \mathrm{P}(5-$ coord): $x\left(g^{-}\right)=0.18-0.33$, whereas the $g^{-}$population around $\mathrm{C}^{1}-\mathrm{C}^{2}$, with $\mathrm{O}-1$ and $\mathrm{O}-2$ trans located, decreases [for $\mathrm{CDCl}_{3}, \mathrm{P}\left(4\right.$-coord): $x\left(\mathrm{~g}^{-}\right)=0.17-0.25: \mathrm{P}(5$-coord): $\left.x\left(g^{-}\right)=0.08-0.12\right]$. As the results point out, the coordinational change of phosphorus is transmitted into specific conformational changes in the glyceryl backbone. This conformational transmission effect originates from the enhanced electron density on $\mathrm{O}-3$ in the $\mathrm{P}(5$-coord $) \mathrm{TBP}$, when the glyceryl moiety is located in the axis of the TBP, resulting in increased $\mathrm{O}-2-\mathrm{O}-3$ and $\mathrm{O}-1-\mathrm{O}-3$ repulsions with respect to the P(4-coord) counterpart. Fig. 4 demonstrates the coupled conformational changes which take place on increasing the coordination from $\mathrm{P}(4$-coord $)$ to a $\mathrm{P}(5$-coord $) \mathrm{TBP}$. The enhanced $\mathrm{O}-2-\mathrm{O}-3$ repulsion shifts the rotameric distribution around the $\mathrm{C}^{2}-\mathrm{C}^{3}$ bond towards $g^{-}$. Consequently, in the $g^{-}$ conformation around $\mathrm{C}^{1}-\mathrm{C}^{2}$, the repulsion between $\mathrm{O}-1$ and $\mathrm{O}-3$ increases. From Dreiding models it follows that in the particular arrangement in which a $g^{-}$conformation around $\mathrm{C}^{1}-\mathrm{C}^{2}$ and $\mathrm{C}^{2}-\mathrm{C}^{3}$ is adopted, the interatomic distance between $\mathrm{O}-1$ and $\mathrm{O}-3$ is comparable to the $\mathrm{O}-2-\mathrm{O}-3$ distance in the 


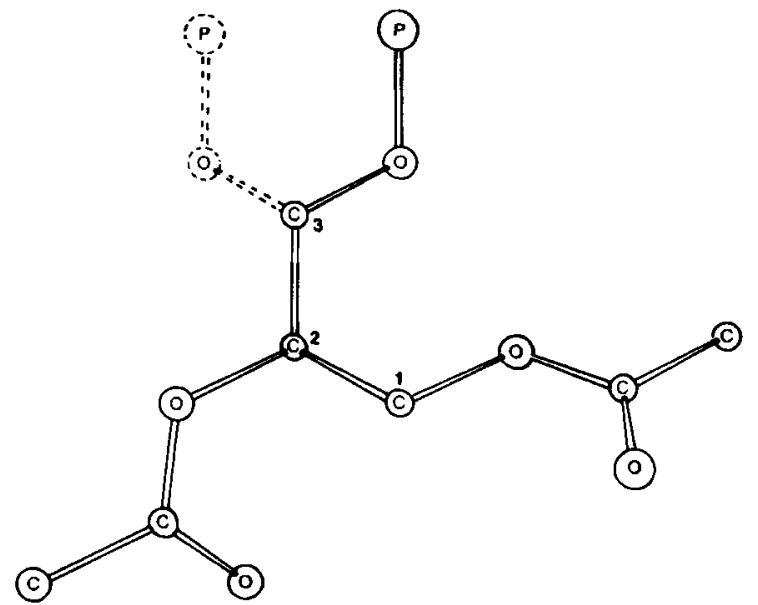

Fig. 4. ORTEP drawing of the glyceryl fragment. The bold lines represent the $g^{-}, g^{-}$arrangement of the glyceryl backbone. The dotted lines show the phosphoryl group trans with respect to $\mathrm{C}-1$. The similarity in interatomic distances between $\mathrm{O}-1$ and $\mathrm{O}-3$ in the $g^{-}, g^{-}$ arrangement and between $\mathrm{O}-2$ and $\mathrm{O}-3$ in the $g^{t}$ conformer around $\mathrm{C}^{2}-\mathrm{C}^{3}$ is obvious

Table $3 .{ }^{13} \mathrm{C}$ deshieldings upon a coordinational change of phosphorus from $P$ (4-coord) to $P$ (5-coord) $T B P$ for compound 2 in $C D C l_{3}$ Concentration: $140 \mathrm{mg} / \mathrm{ml}$. Measurement conditions were kept as equal as possible. C-16 is the terminal methyl group

\begin{tabular}{ll}
$\begin{array}{l}\text { Chain carbon } \\
\text { no. }\end{array}$ & Deshielding \\
\hline 16 & 0 \\
15 & 0 \\
14 & 0 \\
$13^{\mathrm{a}}$ & 0 \\
$12^{\mathrm{a}}$ & 0 \\
$11-5$ & $\mathbf{0 . 0 1}$ \\
4 & $\mathbf{0 . 0 1}$ \\
3 & $0.11^{\mathrm{b}}$ \\
2 & 0.06 \\
& $0.19^{\mathrm{b}}$ \\
& 0.13 \\
\hline
\end{tabular}

a Resonances could not be assigned properly.

${ }^{b}$ Downfield resonance.

$\mathrm{g}^{+}$or $\mathrm{g}^{t}$ conformer around $\mathrm{C}^{2}-\mathrm{C}^{3}$ (approximately $0.27 \mathrm{~nm}$ ). Relaxation of this energetically unfavourable geometry results in a decreased $g^{-}$population around the $C^{1}-C^{2}$ linkage, leading to a decrease in the interchain distance.

Consistent with the electrostatic nature of the oxygenoxygen repulsion is the observation that in compound 5 , where the 2-ester group is substituted by an alkyl moiety, no conformational changes could be detected around the $\mathrm{C}^{2}$ $\mathrm{C}^{3}$ bond on going from a $\mathrm{P}(4$-coord $)$ to a $\mathrm{P}(5$-coord $) \mathrm{TBP}$ geometry. Concerning the $\mathrm{C}^{1}-\mathrm{C}^{2}$ bond a slight increase in $g^{-}$ conformation is observed in the $\mathrm{P}(5$-coord) TBP with respect to the $\mathrm{P}\left(4\right.$-coord) counterpart ${ }^{2}$, which is in contrast to the results on the 2-ester analogues (see above).

${ }^{2}$ In this $\mathrm{P}(5$-coord $)$ compound the assignment of $\mathrm{H}-1 S$ and $\mathrm{H}-1 R$ most likely reverses, otherwise the $g^{-}$conformer will contribute to an improbably high extent, which is in sharp contrast with the wellknown parallel alignment of the hydrocarbon chains [2].
The conformational changes about the $\mathrm{C}^{2}-\mathrm{C}^{3}$ bond in the $\mathrm{P}(5$-coord $)$ TBP compounds $1 \mathrm{~b}-4 \mathrm{~b}$, on varying solvent polarity, show behaviour similar to that observed for the $\mathrm{P}(4-$ coord) derivatives.

It should be mentioned, however, that the coupling constants, from which the rotamer distributions are derived, are measured under rapid phosphorus pseudorotation conditions, as could be judged from the magnetic equivalence of the pseudo-axially and pseudo-equatorially orientated methyl groups in the $\mathrm{P}(5$-coord) TBP. This process leads to timeaveraged conformational distributions in which axially and equatorially located glyceryl fragments both participate. Therefore, it can reasonably be expected that in $\mathrm{P}(5$-coord $)$ TBP compounds with the glyceryl moiety on a distinct axial position, the observed transmission effect will be even more pronounced.

Nonetheless, the results presented here clearly demonstrate that conformational changes take place in the glyceryl backbone of phospholipids when the coordinational number is increased from $\mathrm{P}(4$-coord $)$ to $\mathrm{P}$ (5-coord) TBP and when varying external factors like solvent polarity. In order to investigate whether these conformational changes are carried over in any shifts in the conformational equilibria of the alkyl part of the acyl chain, a ${ }^{13} \mathrm{C}$ NMR analysis was performed. As was shown in this laboratory, ${ }^{13} \mathrm{C}$ NMR chemical shifts are a sensitive probe for changes in conformational equilibria [7]. The data in Table 3 reveal that the ${ }^{13} \mathrm{C}$ chemical shifts do not reflect substantial changes in conformational equilibria in the alkyl part of the phospholipid upon a $\mathrm{P}(4$-coord $)$ to $\mathrm{P}(5$ coord) TBP transition. The deshielding effect on C-2 and $\mathrm{C}-3$ of the hydrocarbon chain is most likely due to a charge redistribution in the ester moiety as a consequence of the $\mathrm{P}$ (4-coord) into $\mathrm{P}$ (5-coord) TBP transition.

When any conformational changes in the alkyl part occurred they would be most easily brought about in the studied monomeric phospholipids. Therefore, it is to be expected that in more condensed phases, with much larger interchain interactions, such conformational changes are even less probable. Thus one might very well surmise that in condensed phases those conformational changes in head-group and/or glyceryl backbone, which result in a change in the effective chain length difference between the $s n-1$ and $s n-2$ hydrocarbon chain, will be compensated almost exclusively by changes in the angle of tilt of the hydrocarbon chains relative to the bilayer normal [21]. The other possibility of changing the effective chainlength difference, that is by a dissimilar shift in the conformational equilibria in the $s n-1$ and $s n-2$ hydrocarbon chains, can be ruled out in view of the ${ }^{13} \mathrm{C}$ chemical shift data.

Our results are in good agreement with the observed invariability of the hydrocarbon chain conformation in dihexadecylphosphatidic acid upon proton dissociation [21]. One might reasonably expect that the negative charge on the phosphate head-group is partly transferred to $\mathrm{O}-3$, as preliminary results indeed indicate. The resulting enhanced electron density will give rise to similar conformational changes as described for the transition from P(4-coord) into $\mathrm{P}$ (5-coord) TBP (see above).

Furthermore, the outcome described in this paper gives some further experimental support for the role of short living $\mathrm{P}$ (5-coord) TBP intermediates in the ion-transport mechanism through membranes, as was worked out by Merkelbach and Buck $[3,4]$. Their experimental results, based on the sodium transport rate through vesicles with incorporated gramicidin $A$ as a function of the phospholipid composition, suggest a correlation between the ease of formation of a $\mathrm{P}(5$-coord) 
Table 4. Experimental data and synthetic procedures followed for the P(4-coord) and P(5-coord) TBP phospholipid model compounds TMS. tetramethylsilane

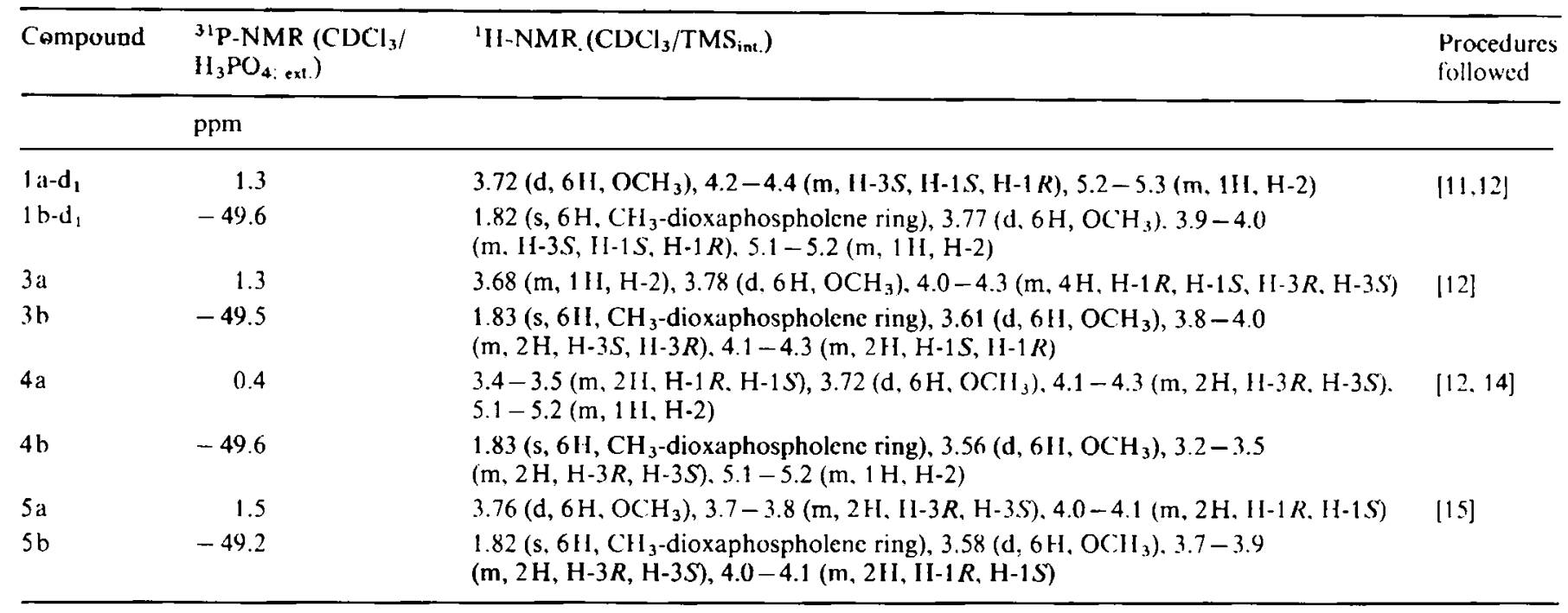

TBP and the ion transport rate. In case of phosphatidylserine a considerable rate acceleration of at least $10^{2}$ was observed with respect to phosphatidylcholine. This finding was ascribed to the availability of the carboxy group of phosphatidylserine. serving as the axial fifth ligand, to build up a P(5-coord) TBP. To make an estimate of the amount of P(5-coord) TBP in the case of phosphatidylserine we took the hydrolysis of diaryl2-carboxyphenyl phosphates, catalyzed by the neighbouring group participation of the carboxylate anion, as a reference [22]. The equilibrium constant for the interconversion between the $\mathrm{P}(5$-coord $) \mathrm{THP}$ intermediate and the starting phosphate was $10^{-6}$. Transferring this value to the phosphatidylserine, it means that about $10^{-4} \%$ exists in a TBP form. (It must be emphasized that in the given examplc from literature [22] the excellent leaving-group capacity of the aryl-oxygen ligands also leads to the irreversible formation of $\mathrm{P}(4$-coord $)$ products. a situation which cannot occur in the regular phospholipids.) Therefore we consider the $\mathrm{P}(5$-coord) TBP as a realistic intermediate for triggering a phase transition, which consequently will lead to the onset of ion-transport (see below). Such phase transition is envisaged as the result of a change in the angle of tilt of the hydrocarbon chains, which is brought about by the enhanced oxygen-oxygen repulsions in the $P(5$-coord $) T B P$ [3]. A cooperative change in the angle of tilt of a number of phospholipid molecules will be needed to maximize the van der Waals interactions between neighbouring acyl chains. This will lead at macromolecular level to the formation of a cluster with an average angle of tilt differing from the surrounding matrix and with a much longer lifetime than the $\mathrm{P}(5$-coord) TBP intermediate. In this model a correlation is supposed between protein activation and the uptake in a cluster of different fluidity. $\Lambda$ transfer of glyceryl backbone conformational changes into shifts in the gauche/trans conformational equilibria in the hydrophobic part of the phospholipid as an alternative for changing tilt angles was not taken into account. Our present results justify this choice.

We wish to thank Dr L. H. Koole for valuable discussions, and Mr L. J. M. van de Ven for his help in recording and interpreting the NMR spectra.

\section{REFERENCES}

1. Hauser, H., Pascher, I., Pearson, R. H. \& Sundell. S. (1981) Biochim. Biophys. Acta 650.21-51.

2. Hauser, H., Giuyer, W., Pascher, I., Skrabal, P. \& Sundell, S. (1980) Biochemistry 19.366-373.

3. Merkelbach. I. I. (1985) Thesis, Eindhoven University of Technology.

4. Merkelbach, I. I. \& Buck, H. M. (1983) Recl. Trav. (him. PaysBas 102, 283-284.

5. Koole, L. H.. Lanters, E. J. \& Buck. H. M. (1984) .I. Am. Chem. Soc. $106,5451-5457$.

6. Koolc, L. H., van Kooyk, R. J. L. \& Buck. H. M. (1985) J. Am. Chem. Soc. 107, 4032-4037.

7. de Weerd, R. J. E. M., de Haan, J. W., van de Ven, L. J. M.. Achten, M. \& Buck, H. M. (1982) J. Phy's. Chem. 86. $2528-$ 2533.

8. Akutsu, H. \& Kyogoku, Y. (1977) Chem. Phys. Lipids 18. $285-$ 303.

9. Lecocq, J. \& Ballou, C. E. (1964) Biochemistry 3, 976-980

10. Jensen. R. G. \& Pitas, R. E. (1976) Adv. Lip. Res. 14, $213-247$

11. Bruzik, K., Jiang, R. \& Tsai. M. (1983) Biochemistry 22. 24782486.

12. Howe, R. J. \& Malkin, T. J. (1951) J. Chem. Soc. 2663-2667.

13. Lippman, A. E. (1965) J. Org. Chem. 30, 3217-3219.

14. Buchnea, D. (1971) Lipids 6. 734-739.

15. Mercier, C., Addas, A. R. \& Deslongchamps, P. (1972) Can. J. Chem. 50, $1882-1885$.

16. Wohlgemuth, R., Waespe-Sarčevic. N. \& Scelig. J. (1980) Biochemistry 19, 3315-3321.

17. Günther, H., Kellner, M., Biller. F. \& Simon, II. (1973) Angew: Chem. 85, $141-142$.

18. Batiz-Hernandes, H. \& Bernheim, R. A. (1967) Prog. Nucl. Magnet. Resonance Spectrosc. 3, 67-85.

19. Haasnoot, C. A. G., de Lecuw, F. A. A. M. \& Altona, C. (1980) Tetrahedron 36, $2783-2792$.

20. Wolfe, S. (1972) Acc. Chem. Res. 5, 102.

21. Jähnig, F.. Harlos, K., Vogel, H. \& Eibl. H. (1979) Biochemistry I8. $1461-1468$.

22. Bromilow, R. H., Khan, S. A. \& Kirby, A. J. (1972) J. Chem. Soc. Perkin $I I, 911-918$. 